\title{
PENGARUH KEPEMIMPINAN DAN DISIPLIN KERJA TERHADAP KINERJA KARYAWAN PADA PT. INDOSAT TBK JAKARTA SELATAN
}

\author{
Widia Astuti \\ email:dosen01265@unpam.ac.id
}

\begin{abstract}
ABSTRAK
Tujuan penelitian ini untuk mengetahui pengaruh kepemimpinan dan disiplin kerja terhadap kinerja karyawan PT. Indosat Tbk Jakarta.

Data yang digunakan dalam penelitian ini primer yang bersumber dari hasil kuesioner diambil dari 125 responden di PT. Indosat Tbk Jakarta. Sampel yang digunakan berupa sampel jenuh. Menggunakan metode kuantitatif. Variabel independent dan variabel dependent. Motode analisis yang digunakan dalam penelitian ini adalah dengan menggunakan spss 25 , analisis statistic meliputi uji asumsi klasik, regresi linier berganda, dan koefisien determinasi. Sedangkan pengujian hipotesis yang digunakan adalah motode statistik uji validitas, uji reliabilitas, uji t dan uji f. Pada skripsi ini penulis melakukan penelitian kepemimpinan dan disiplin sebagai dasar untuk mengukur kinerja karyawan pada PT. Indosat Tbk Jakarta sesuai dengan permasalahan yang akan diteliti.

Hasil analisis pengaruh kepemimpinan dan disiplin terhadap kinerja karyawan pada PT. Indosat Tbk Jakarta nilai korelasi sederhana $=0,857$ artinya kepemimpinan dan disiplin memiliki tingkat hubungan sedang terhadap kinerja karyawan. Persamaan regresi linier berganda didapat $\mathrm{Y}=$ $4.097+0,48 X_{1}+0,53 X_{2}$. Nilai koefisien determinasi sebesar $72 \%$ menunjukan bahwa besarnya variabel kepemimpinan dan disiplin dalam upaya meningkakan kinerja karyawan sisanya $28 \%$ dipengaruhi oleh variabel lain yang tidak diteliti dalam penelitian ini. Setelah dilakukan uji signifikan dengan menggunakan "uji $t$ ", diperoleh bahwa $t_{\text {hitung }}>t$ tabel yaitu 4,320 $>2,007$ yang artinya $\mathrm{H}_{\mathrm{o}}$ ditolak dan $\mathrm{H}_{\mathrm{a}}$ diterima, ini berarti ada pengaruh yang signifikan antara kepemimpinan dan disiplin terhadap kinerja karyawan pada PT. Indosat Tbk Jakarta
\end{abstract}

\section{Kata Kunci : Kepemimpinan, Disiplin dan Kinerja}

\section{ABSTRACT}

The purpose of this study was to determine the effect of leadership and work discipline on the performance of employees of PT. Indosat Tbk Jakarta.

The data used in this study were sourced primarily from the results of the questionnaire taken from 125 respondents at PT. Indosat Tbk Jakarta. The sample used is a saturated sample. Using quantitative methods. The independent variable and the dependent variable. The analysis method used in this study is to use spss 25 , statistical analysis includes the classical assumption test, multiple linear regression, and the coefficient of determination. While testing the hypothesis used is a statistical method of validity test, reliability test, $\mathrm{t}$ test and $\mathrm{f}$ test. In this thesis the author conducts leadership and discipline research as a basis for measuring employee performance at PT. Indosat Tbk Jakarta in accordance with the issues to be examined.

The results of the analysis of the influence of leadership and discipline on employee performance at PT. Indosat Tbk Jakarta simple correlation value $=0.857$ means that leadership and discipline have a moderate level of relationship to employee performance. The multiple linear regression equation is obtained $\mathrm{Y}=4.097+0.48 \mathrm{X} 1+0.53 \mathrm{X} 2$. The coefficient of determination of $72 \%$ indicates that the magnitude of the leadership and discipline variables in an effort to improve employee performance 
the remaining $28 \%$ is influenced by other variables not examined in this study. After doing a significant

test using the "t test", it was found that the tcount $>t$ table is 4,320 > 2,007 which means that Ho was rejected and $\mathrm{Ha}$ was accepted, this meant that there was a significant influence between leadership and discipline on employee performance at PT. Indosat Tbk Jakarta

\section{Keywords: Leadership, Discipline and Performance}

\section{A. PENDAhUluaN}

Sumber daya manusia merupakan aset utama bagi setiap perusahaan yang menjadi perencana dan pelaku aktif berbagai aktifitas dalam suatu organisasi. Mereka mempunyai pikiran, perasaan, keinginan, status, dan latar belakang pendidikan yang dibawa kedalam suatu lingkungan organisasi perusahaan. Sumber daya manusia bukan seperti uang, mesin, dan materil yang sifatnya positif dan dapat diatur sepenuhnya dalam mendukung tercapainya tujuan perusahaan. Sumber daya manusia sebagai aset yang harus ditingkatkan efisiensi dan produktivitasnya agar perusahaan semakin kompetitif dalam bersaing. Untuk mencapai hal tersebut, maka organisasi harus mampu menciptakan kondisi yang dapat mendorong dan memungkinkan karyawan untuk mengembangkan dan meningkatkan kemampuan serta keterampilan yang dimiliki secara optimal.

Pengelolaan sumber daya manusia yang dimaksudkan adalah bahwa perusahaan harus mampu untuk menyatukan persepsi atau cara pandang karyawan dan pimpinan perusahaan dalam rangka mencapai tujuan perusahaan antara lain melalui pembentukan mental bekerja yang baik dengan dedikasi dan loyalitas tinggi terhadap pekerjaannya, memberikan bimbingan, pengarahan dan koordinasi yang baik dalam bekerja oleh seorang pemimpin kepada bawahannya.

Dalam menjawab tantangan tersebut setiap perusahaan harus mempersiapkan tenaga kerja yang handal dalam berbagai bidang masig-masing. Pada dasarnya sumber daya manusia adalah suatu sumber daya yang sangat dibutuhkan oleh suatu organisasi. Hal ini dikarenakan sumber daya manusia adalah sumber yang berperan aktif terhadap jalannya suatu organisasi dan proses pengambilan keputusan.
Dalam organisasi, faktor kepemimpinan memegang peranan yang sangat penting karena pemimpin itulah yang akan menggerakkan dan mengarahkan organisasi dalam mencapai tujuan dan sekaligus merupakan tugas yang sangat tidak mudah, karena harus memahami setiap perilaku bawahan yang berbeda-beda.

Kepemimpinan menurut Amirullah (2015:167) adalah "orang yang memiliki wewenang untuk memberi tugas, mempunyai kemampuan untuk membujuk atau mempengaruhi orang lain dengan melalui pola hubungan yang baik guna mencapai tujuan yang telah ditentukan. Mengacu pada pernyataan tersebut bahwa seorang pemimpin adalah salah satu unsur yang menentukan dalam mengembangkan perusahaan. Berhasil tidak nya perusahaan banyak ditentukan oleh kualitas kepemimpinan yang dijalankan perusahaan tersebut".

Selain itu, agar tercipta hasil kerja yang maksimal kedisiplinan turut berperan dalam mendorong kinerja karyawan. Karena didalam kedisiplinan mengandung makna pengendalian diri dan kumpulan beberapa tata tertib yang berfungsi mengatur tingkah laku. Hal ini sesuai dengan yang dikemukakan oleh Hasibuan (2007:193) dimana "kedisiplinan adalah bentuk kesadaran dan kesediaan seseorang menaati semua peraturan perusahaan yang ada dan norma-norma sosial yang berlaku di perusahaan".Kedisiplinan harus ditegakkan dalam suatu organisasi perusahaan. Tanpa dukungan disiplin karyawan yang baik, sulit bagi perusahaan untuk mewujudkan tujuannya.

Setiap perusahaan atau organisasi harus menerapkan berbagai peraturan dan tata tertib agar tercipta kedisiplinan dalam menjalankan dan melaksanakan tugas dan tanggung jawabnya. Aturan atau norma itu biasanya diikuti dengan sanksi yang diberikan 
bila terjadi pelanggaran. Sanksi tersebut bisa berupa teguran, skorsing, penurunan pangkat, bahkan sampai pemecatan. Hal itu dilakukan agar para karyawan bekerja dengan disiplin dan bertanggung jawab atas pekerjaannya. Ukuran yang dapat dipakai dalam menilai

apakah pegawai tersebut disiplin atau tidak dapat terlihat dari ketepatan waktu kerja maupun penggunaan sarana atau fasilitas perusahaan secara efektif dan efisien.

Mengingat pentingnya motivasi, maka wujud perhatian pihak perusahaan mengenai masalah motivasi kerja salah satunya melakukan pemotivasian karyawan melaui serangkaian usaha tertentu sesuai dengan kebijakan perusahaan, sehingga motivasi karyawan dalam bekerja akan tetap terjaga. Untuk memotivasi karyawan, pemimpin harus mengetahui motif dan motivasi yang diinginkan oleh karyawan, satu hal yang harus dipahami bahwa seseorang akan mau bekerja karena meraka ingin memenuhi kebutuhannya, baik dalam bentuk materi dan non materi, kebutuhan fisik maupun rohani.

Kreitner dan Kinicki dalam Amirullah (2009:219) mengemukakan bahwa "motivasi merupakan proses psikologis yang meningkatkan dan mengarahkan perilaku untuk mencapai tujuan". Menurunnya kinerja karyawan dapat disebabkan kurangnya motivasi terhadap karyawan sehingga menimbulkan rasa jenuh dalam menjalankan pekerjaan yang telah diberikan. Motivasi kerja karyawan dalam suatu organisasi dapat dianggap sederhana dan dapat pula menjadi masalah yang kompleks, karena pada dasarnya manusia mudah untuk dimotivasi dengan memberikan apa yang menjadi keinginannya.

PT Indosat Tbk. adalah salah satu perusahaan penyedia jasa telekomunikasi dan jaringan telekomunikasi di Indonesia. Perusahaan ini menawarkan saluran komunikasi untuk pengguna telepon genggam dengan pilihan pra bayar maupun pascabayar dengan merek jual Matrix Ooredoo, Mentari Ooredoo dan IM3 Ooredo, jasa lainnya yang disediakan adalah saluran komunikasi via suara untuk telepon tetap termasuk sambungan langsung internasional IDD (International Direct Dialing). Indosat
Ooredoo juga menyediakan layanan multimedia, internet dan komunikasi data.

PT. Indosat Tbk memiki Visi dalam mengembangkan perusahaannya, yaitu Menjadi perusahaan penyedia solusi informasi dan komunikasi Pilihan. Sedangkan misi PT. Indosat Tbk yaitu, 1) Menyediakan dan mengembangkan produk layanan dan solusi inovatif dan berkualitas untuk memberikan manfaat yang sebesar besarnya bagi para pelanggan, 2) Meningkatkan shareholder value secara terus menerus, 3) Mewujudkan kualitas kehidupan stakeholder yang lebih baik.

Kinerja karyawan PT. Indosat Tbk juga dapat diukur melalui penyelesaian tugasnya secara efektif dan efisien serta melakukan peran dan fungsinya yang positif bagi keberhasilan suatu perusahaan. Terdapat faktor negatif yang dapat menurunkan kinerja karyawan, diantaranya adalah menurunnya keinginan karyawan untuk mencapai prestasi kerja, kurangnya ketepatan waktu dalam penyelesaian pekerjaan sehingga kurang mentaati peraturan, pengaruh yang berasal dari lingkungannya, teman sekerja yang juga menurun semangatnya dan tidak adanya contoh yang harus dijadikan acuan dalam pencapaian prestasi kerja yang baik. Semua itu merupakan sebab menurunya kinerja karyawan dalam bekerja. Faktor-faktor yang dapat digunakan untuk meningkatkan kinerja diantaranya adalah kepemimpinan, motivasi dan disiplin kerja.

Prosentase karyawan yang datang terlambat melebihi batas toleransi yang telah ditentukan atau tiba di kantor melebihi dari pukul 08.15 WIB cukup tinggi. Karyawan yang tiba terlambat ini seharusnya melakukan kompensasi dengan memundurkan jam kepulangannya dari kantor. Namun hal ini seringkali tidak dilakukan. Menurut peraturan yang ditetapkan, karyawan yang tiba dikantor pukul 08.16 WIB baru boleh pulang pada pukul 17.16 WIB. Hal tersebut menunjukan bahwa tingkat kedisiplinan karyawan masih rendah dalam mentaati peraturan yang berlaku di PT. Indosat Tbk

Selain itu selama tahun 2019 karyawan yang tidak masuk tanpa keterangan cukup tinggi, begitu juga dengan yang mengajukan izin dan cuti. Tentunya ini 
menunjukan bahwa tingkat kedisiplinan karyawan pada PT. Indosat Tbk masih rendah dan dapat berdampak pada kinerja karyawan Hal tersebut sesuai dengan jurnal penelitian yang dilakukan oleh Brigita Ria Tumilaar, "Pengaruh Disiplin, Gaya Kepemimpinan, Dan Motivasi Terhadap Kinerja Karyawan Pada BPJS Ketenagakerjaan

Sulut",Vol.3 No.2 Juni 2015, Hal. 787-797. Bahwa kedisiplinan berpengaruh signifikan terhadap kinerja karyawan.

Dengan timbulnya permasalahan karyawan yang nilainya negatif akan berpengaruh terhadap kinerja, kualitas pekerjaan yang menurun bahkan kesalahan yang terjadi cenderung kurang disiplin. Permasalahan ini merupakan indikasi bahwa telah terjadi penurunan kinerja pada saat kurang disiplin dan pengawasan, oleh karena itu PT. Indosat Tbk harus melakukan audit sistem secara menyeluruh untuk meningkatkan kinerja karyawan dan mempertahankan keberlangsungan perusahaan.

Kurangnya pengawasan dan motivasi dalam setiap divisi dan tegas dalam menyikapi kesalahan yang seharusnya tidak terulang. Timbulnya berbagai permasalahan terletak pada fungsi pemimpin yang kurang tegas dan kurang melakukan evaluasi serta tidak efektifnya pemimpin memonitor setiap harinya, sehingga menimbulkan menurunnya motivasi karyawan yang akan berimbas pada kinerja karyawan yang kurang maksimal.

Kepemimpinan merupakan unsur penting dalam perusahaan, tanpa adanya kepemimpinan dari seorang pemimpin maka suatu perusahaan tersebut akan mengalami kemunduran. Setiap pemimpin pada dasarnya memiliki perilaku yang berbeda dalam memimpin. Kepemimpinan yang dijalankan oleh seorang pemimpin dalam mempengaruhi perilaku orang lain sesuai dengan keinginannya itu dipengaruhi oleh sifat pemimpin itu sendiri.

Kepemimpinan yang baik akan menciptakan motivasi yang tinggi di dalam diri setiap bawahan, sehingga dengan motivasi tersebut akan timbul semangat kerja yang dapat meningkatkan kinerja dari bawahan itu.

Dari berbagai permasalahan yang telah diuraikan diatas, jika suatu pemimpin telah menerapkan pola atau gaya kepemimpinan yang pas, sehingga dapat meningkatkan kedisiplinan karyawan dan secara langsung berdampak pada peningkatan motivasi karyawan dan jika keseluruhan faktor-faktor tersebut dapat diterapkan secara bersamaan pada suatu perusahaan, maka dapat dipastikan perusahaan tersebut akan menghasilkan kinerja yang jauh lebih baik, walaupun ada berbagai faktor yang menjadi penghambat dalam meningkatkan kinerja. Untuk itulah penelitian ini sangat penting karena selain untuk mengetahui tingkat kinerja karyawan, penelitian ini juga diharapkan akan dapat menjelaskan aspekaspek yang mendukung dan aspek-aspek yang menghambat kinerja khususnya pada PT. Indosat Tbk Jakarta Selatan.

Berdasarkan uraian tersebut diatas, penulis merasa tertarik untuk melakukan penelitian dengan judul "Pengaruh Kepemimpinan dan Disiplin Kerja Terhadap Kinerja Karyawan Pada PT. Indosat Tbk Jakarta Selatan".

\section{Identifikasi Masalah}

a. Kurang tegasnya seorang pemimpin dalam memimpin bawahannya.

b. Lemahnya pengawasan yang dilakukan pimpinan terhadap bawahan

c. Belum adanya kepemimpinan yang pas dalam penerapan sistem kerja di lingkungan perusahaan.

d. Tingkat kedisiplinan karyawan masih rendah dalam mentaati peraturan yang berlaku di PT. Indosat Tbk.

e. Turunnya kinerja pegawai yang ditunjukan oleh tingkat pencapaian kinerja yang belum optimal.

\section{Perumusan Masalah}

a. Apakah kepemimpinan berpengaruh positif dan signifikan terhadap kinerja karyawan pada PT. Indosat Tbk Jakarta?

b. Apakah disiplin kerja berpengaruh positif dan signifikan terhadap kinerja karyawan pada PT. Indosat Tbk Jakarta?

c. Apakah kepemimpinan dan disiplin kerja berpengaruh positif dan signifikan secara bersama-sama terhadap kinerja karyawan pada PT. 
Indosat Tbk Jakarta?

\section{B. KAJIAN LITERATUR}

\section{Kepemiminan}

Menurut

Thoha

(2009:9)

"Kepemimpinan adalah kegiatan untuk mempengaruhi perilaku orang lain, atau seni mempengaruhi perilaku manusia baik perorangan maupun kelompok". Kepemimpinan tidak harus dibatasi oleh

aturan - aturan atau tata krama dan birokrasi. Kepemimpinan tidak harus diikat dalam suatu oragnisasi tertentu. Melainkan kepemimpinan bisa terjadi dimana saja, asalkan seseorang menunjukkan kemampuannya mempengaruhi perilaku orang-orang lain kearah tercapainya suatu tujuan tertentu".

\section{Indikator Kepemimpinan}

1) Watak dan kepribadian yang terpuji

2) Keinginan melayani bawahan

3) Memahami kondisi lingkungan

4) Intelegensi yang tinggi

5) Berorientasi kedepan

6) Sikap terbuka dan lugas

\section{Kedisiplinan}

Menurut Henry Simamora (2013:610)

"Disiplin adalah prosedur yang mengoreksi atau menghukum bawahan karena melanggar peraturan atau prosedur. Disiplin merupakan pengendalian diri karyawan dan pelaksanaan yang teratur dan menunjukkan tingkat kesungguhan tim kerja di dalam sebuah organisasi. Tindakan disipliner menuntut suatu hukuman terhadap karyawan yang gagal memenuhi standar yang ditatapkan. Tindakan disipliner yang efektif terpusat pada perilaku karyawan yang salah, bukan pada diri karyawan sebagai pribadi".

\section{Indikator Disiplin Kerja}

1) Tujuan dan kemampuan

2) Teladan pimpinan

3) Balas jasa

4) Keadilan

5) Waskat (Pengawasan Melekat)

6) Sanksi hukuman

7) Ketegasan

8) Hubungan kemanusiaan

\section{Kinerja}

Menurut Wibowo (2011:7), "kinerja berasal dari pengertian performance, ada pula yang memberikan pengertian performance sebagai hasil kerja atau prestasi kerja, namun sebenarnya kinerja mempunyai makna yang lebih luas, bukan hanya hasil kerja, tetapi termasuk bagaimana proses pekerjaan berlangsung".

Indikator Kinerja

1) Kualitas

2) Kuantitas

3) Ketepatan waktu

4) Efektivitas

5) Kemandirian

6) Komitmen kerja

\section{Kerangka Berpikir}

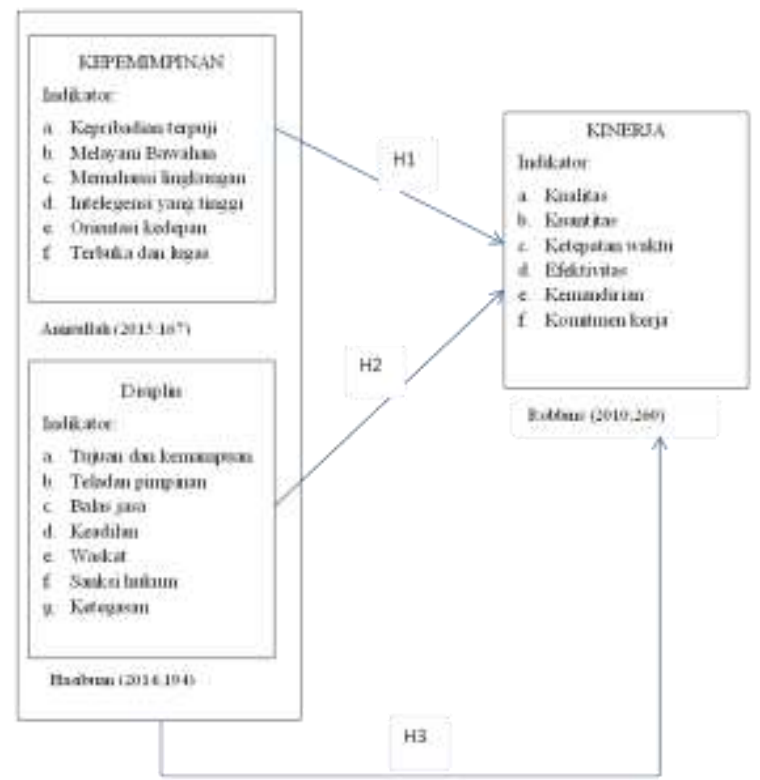

\section{METODOLOGI PENELITIAN}

Jenis penelitian yang digunakan dalam penelitian ini adalah penelitian kuantitatif, yang artinya penelitian dilakukan berdasarkan teori yang telah ada dan untuk mengetahui hubungan kepemimpinan dan moivasi sebagai variable bebas dan kinerja karyawan sebagai variabel terkait digunakan analisis statistik.

\section{Tempat Penelitian}

Tempat penelitian ini dilaksanakan di PT. Indosat Tbk Podium Depan Lt. Dasar, Jl. Medan 
Merdeka Barat No.21, RT.2/RW.3, Gambir, Kota Jakarta Pusat, Daerah Khusus Ibukota Jakarta 10110.

\section{Waktu Penelitian} dapun waktu yang diperlukan penulis dalam melakukan observasi dan pengumpulan data di tempat tersebut dilakasanakan selama 5 (lima) bulan mulai bulan April sampai dengan bulan Agustus 2020.

\section{Sifat penelitian}

Penelitian ini dilakukan denagn tujuan untuk dapat mengetahui masalah yang diteliti. Pada penelitian mengenai kepemminan dan motivasi terhadap kinerja karyawan, sifat penelitian ini menggunakan metode kuantitatif asosiasif, artinya peneitian dilakukam berlandasan dengan teori yang telah ada, untuk mengetahui pengaruh antara variabel bebas dan variabel terkait menggunakan analisis statistik.

\section{Populasi dan Sampel Penelitian}

\section{a. Populasi}

Populasi dalam penelitian ini adalah karyawan PT. Indosat Tbk Jakarta, yang berjumlah 125 karyawan.

\section{b. Teknik Pengambilan Sampel}

Dalam menentukan sampel, penulis menggunakan sampling jenuh, sehingga semua jumlah populasi yang ada secara keseluruhan dijadikan sampel. Menurut Sugiyono (2008:85) sampling jenuh adalah teknik penentuan sampel bila semua anggota populasi digunakan sebagai sampel. Jadi sampel peserta dalam penelitian ini adalah 125 orang atau seluruh karyawan PT. Indosat Tbk Jakarta.

\section{Skala Pengumpulan Data}

a. Skala Likert

Dalam imu statistik terdapat berbagai jenis skala pengukuran yang dipelajari dan digunakan demi kepentingan baik secara akademis maupun paktisi. Dan penulis dalam hal ini juga menggunakan salah satu skala yang telah dikembangkan yakni Skala Likert dalam pembobotan data-data yang diperoleh. b. Skala Interval

$$
\mathrm{P}=\frac{\text { Rentang }}{\text { Banyak kelas }}
$$

Dimana :

$\mathrm{P}$

$$
=\text { Panjang Kela }
$$

Interval

$$
\text { Rentang = Data }
$$

Terbesar-Data Terkecil

Banyak Kelas $=5$ (Lima)

Sehingga intervalnya dalam penelitian ini adaah sebagai berikut :

$$
\begin{gathered}
P=\frac{5-1}{5} \\
P=\frac{4}{5} \\
P=0,8
\end{gathered}
$$

\section{Analisis Data}
a. Uji Kualitas Data
1) Uji Validitas
2) Uji Reliabilitas
b. Uji Asumsi Klasik
1) Uji Normalitas
2) Uji Multikolinearitas
3) Uji Heteroskedastisitas
c. Uji Hipotesis
1) Analisis Regresi Linear Berganda
2) Uji t (Parsial)
d. Uji F (Simultan)
e. Koefisien Determinas

\section{HASIL DAN PEMBAHASAN}

\section{Uji Validitas}

a. Variabel Kepemimpinan

\begin{tabular}{|c|l|c|c|c|}
\hline No & $\begin{array}{c}\text { Pernyata } \\
\text { an }\end{array}$ & $\begin{array}{c}\text { rhitun } \\
\boldsymbol{g}\end{array}$ & $\boldsymbol{r}$ tabel & $\begin{array}{c}\text { Keteran } \\
\text { gan }\end{array}$ \\
\hline 1 & Kep_1 & 0.777 & 0,175 & Valid \\
\hline 2 & Kep_2 & 0.691 & 0,175 & Valid \\
\hline 3 & Kep_3 & 0.721 & 0,175 & Valid \\
\hline 4 & Kep_4 & 0.743 & 0,175 & Valid \\
\hline 5 & Kep_5 & 0.626 & 0,175 & Valid \\
\hline 6 & Kep_6 & 0.691 & 0,175 & Valid \\
\hline 7 & Kep_7 & 0.695 & 0,175 & Valid \\
\hline 8 & Kep_8 & 0.769 & 0,175 & Valid \\
\hline 9 & Kep_9 & 0.663 & 0,175 & Valid \\
\hline 10 & Kep_10 & 0.736 & 0,175 & Valid \\
\hline 11 & Kep_11 & 0.495 & 0,175 & Valid \\
\hline 12 & Kep_12 & 0.597 & 0,175 & Valid \\
\hline 13 & Kep_13 & 0.561 & 0,175 & Valid \\
\hline
\end{tabular}


JRNAL ПMПAH P-ISSN 2615-6849, E-ISSN 2622-3686

\begin{tabular}{|c|c|c|c|c|}
\hline No & $\begin{array}{c}\text { Pernyata } \\
\text { an }\end{array}$ & $\begin{array}{c}\text { rhitun } \\
\boldsymbol{g}\end{array}$ & r tabel & $\begin{array}{c}\text { Keteran } \\
\text { gan }\end{array}$ \\
\hline 14 & Kep_14 & 0.443 & 0,175 & Valid \\
\hline 15 & Kep_15 & 0.537 & 0,175 & Valid \\
\hline
\end{tabular}

b. Variabel Disiplin

\begin{tabular}{|c|l|c|c|c|}
\hline No & $\begin{array}{c}\text { Pernyata } \\
\text { an }\end{array}$ & $\begin{array}{c}\text { rhitun } \\
\boldsymbol{g}\end{array}$ & r tabel & $\begin{array}{c}\text { Keteran } \\
\text { gan }\end{array}$ \\
\hline 1 & Dis_1 & 0.791 & 0,175 & Valid \\
\hline 2 & Dis_2 & 0.645 & 0,175 & Valid \\
\hline 3 & Dis_3 & 0.806 & 0,175 & Valid \\
\hline 4 & Dis_4 & 0.747 & 0,175 & Valid \\
\hline 5 & Dis_5 & 0.708 & 0,175 & Valid \\
\hline 6 & Dis_6 & 0.548 & 0,175 & Valid \\
\hline 7 & Dis_7 & 0.696 & 0,175 & Valid \\
\hline 8 & Dis_8 & 0.709 & 0,175 & Valid \\
\hline 9 & Dis_9 & 0.784 & 0,175 & Valid \\
\hline 10 & Dis_10 & 0.702 & 0,175 & Valid \\
\hline 11 & Dis_11 & 0.184 & 0,175 & Valid \\
\hline 12 & Dis_12 & 0.673 & 0,175 & Valid \\
\hline 13 & Dis_13 & 0.668 & 0,175 & Valid \\
\hline 14 & Dis_14 & 0.572 & 0,175 & Valid \\
\hline 15 & Dis_15 & 0.668 & 0,175 & Valid \\
\hline
\end{tabular}

c. Variabel Kinerja

\begin{tabular}{|c|l|c|c|c|}
\hline No & $\begin{array}{c}\text { Pernyata } \\
\text { an }\end{array}$ & $\begin{array}{c}\text { rhitun } \\
\text { g }\end{array}$ & r tabel & $\begin{array}{c}\text { Keteran } \\
\text { gan }\end{array}$ \\
\hline 1 & KK_1 & 0.797 & 0,175 & Valid \\
\hline 2 & KK_2 & 0.651 & 0,175 & Valid \\
\hline 3 & KK_3 & 0.788 & 0,175 & Valid \\
\hline 4 & KK_4 & 0.729 & 0,175 & Valid \\
\hline 5 & KK_5 & 0.700 & 0,175 & Valid \\
\hline 6 & KK_6 & 0.533 & 0,175 & Valid \\
\hline 7 & KK_7 & 0.705 & 0,175 & Valid \\
\hline 8 & KK_8 & 0.700 & 0,175 & Valid \\
\hline 9 & KK_9 & 0.775 & 0,175 & Valid \\
\hline 10 & KK_10 & 0.694 & 0,175 & Valid \\
\hline 11 & KK_11 & 0.534 & 0,175 & Valid \\
\hline 12 & KK_12 & 0.707 & 0,175 & Valid \\
\hline 13 & KK_13 & 0.686 & 0,175 & Valid \\
\hline 14 & KK_14 & 0.588 & 0,175 & Valid \\
\hline 15 & KK_15 & 0.692 & 0,175 & Valid \\
\hline
\end{tabular}

2. Uji Reliabilitas

Hasil Uji Reliabilitas Variabel Kepemimpinan (X1)

Reliability Statistics

Cronbach's Alpha $\quad \mathrm{N}$ of Items

\begin{tabular}{rr}
\hline 925 & 15 \\
\hline
\end{tabular}

Hasil Uji Reliabilitas Variabel Disiplin (X2) Reliability Statistics

\begin{tabular}{r|r} 
Cronbach's Alpha & \multicolumn{1}{c}{ N of Items } \\
\hline .928 & 15 \\
\hline
\end{tabular}

Hasil Uji Reliabilitas Variabel Kinerja Karyawan (Y)

Reliability Statistics

\begin{tabular}{r|r} 
Cronbach's Alpha & N of Items \\
\hline .936 & 15 \\
\hline
\end{tabular}

3. Uji Asumsi Klasik

a. Uji Normalitas

Hasil Uji Normalias Data

One-Sample Kolmogorov-Smirnov Test

Unstandardi

zed

Residual

\begin{tabular}{llr}
\hline $\mathrm{N}$ & & 125 \\
\hline Normal & Mean & .0000000 \\
\cline { 2 - 3 } Parameters $^{\mathrm{a}, \mathrm{b}}$ & Std. & .74217828 \\
& Deviation & \\
\hline Most Extreme & Absolute & .092 \\
\cline { 2 - 3 } Differences & Positive & .044 \\
\cline { 2 - 3 } & Negative & -.092 \\
\hline Test Statistic & & .092 \\
\hline Asymp. Sig. (2-tailed) & $.011^{\mathrm{c}}$ \\
\hline
\end{tabular}

a. Test distribution is Normal.

b. Calculated from data.

c. Lilliefors Significance Correction.

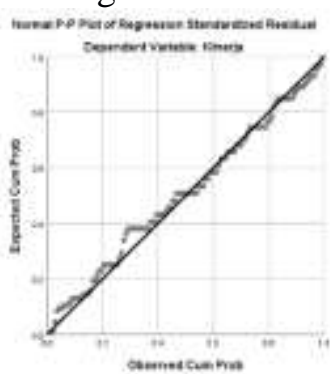

P-Plot Uji Normalitas Data

b. Uji Multikolinearitas

Hasil Uji Multikolinearitas

Coefficients $^{\mathbf{a}}$

\begin{tabular}{l|l} 
Model Collinearity Statistics
\end{tabular} 


\begin{tabular}{ll|l|l} 
& & Tolerance & \multicolumn{1}{c}{ VIF } \\
\hline 1 & (Constant) & & \\
\cline { 2 - 4 } & Kepemimpinan & .403 & 2.482 \\
\cline { 2 - 4 } & Disiplin & .403 & 2.482 \\
\hline
\end{tabular}

c. Uji Heterokedastisitas

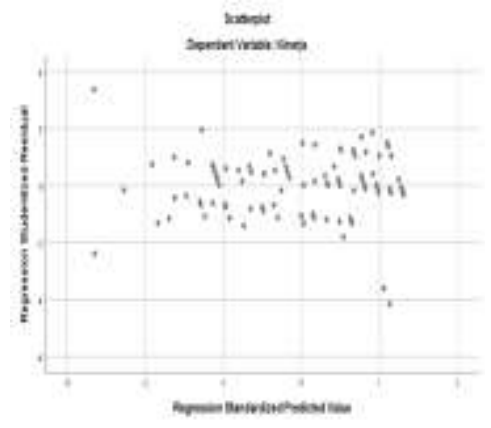

Histogram Uji Heterokedastisitas

A. Uji Hipotesis

\section{Uji t Parsial}

Hasil Uji t Variabel Kepemimpinan (X1) terhadap Kinerja Karyawan (Y) Coefficients $^{\mathrm{a}}$

\begin{tabular}{|c|c|c|c|c|c|}
\hline & \multicolumn{2}{|c|}{$\begin{array}{c}\text { Unstandardiz } \\
\text { ed } \\
\text { Coefficients }\end{array}$} & $\begin{array}{l}\text { Standa } \\
\text { rdized } \\
\text { Coeffi } \\
\text { cients }\end{array}$ & & \\
\hline Model & B & $\begin{array}{l}\text { Std. } \\
\text { Error }\end{array}$ & Beta & $\mathrm{t}$ & Sig. \\
\hline $\begin{array}{ll}1 & \text { (Consta } \\
\text { nt) }\end{array}$ & $\begin{array}{r}15.10 \\
5\end{array}$ & 3.674 & & $\begin{array}{r}4.11 \\
1\end{array}$ & .000 \\
\hline $\begin{array}{l}\text { Kepemi } \\
\text { mpinan }\end{array}$ & .778 & .055 & .787 & $\begin{array}{r}14.1 \\
38 \\
\end{array}$ & .000 \\
\hline
\end{tabular}

a. Dependent Variable: Kinerja

\begin{tabular}{|c|c|c|c|c|c|}
\hline \multicolumn{6}{|c|}{$\begin{array}{c}\text { Hasil Uji t Variabel DIsiplin (X2) } \\
\text { Kinerja Karyawan (Y) }_{\text {Coefficients }^{\mathbf{a}}}\end{array}$} \\
\hline \multirow[b]{2}{*}{ Model } & $\begin{array}{l}\text { Unstan } \\
\text { d Coef }\end{array}$ & $\begin{array}{l}\text { lardize } \\
\text { icients }\end{array}$ & $\begin{array}{l}\text { Standa } \\
\text { rdized } \\
\text { Coeffi } \\
\text { cients }\end{array}$ & & \\
\hline & B & $\begin{array}{l}\text { Std. } \\
\text { Error }\end{array}$ & Beta & $\mathrm{t}$ & Sig. \\
\hline $\begin{array}{ll}1 & \text { (Con } \\
\text { stant })\end{array}$ & -2.831 & .750 & & $\begin{array}{r}3.77 \\
7 \\
\end{array}$ & .000 \\
\hline $\begin{array}{l}\text { Disip } \\
\text { lin }\end{array}$ & 1.040 & .011 & .993 & $\begin{array}{r}3.29 \\
2 \\
\end{array}$ & .000 \\
\hline
\end{tabular}

a. Dependent Variable: Kinerja

2. Uji F Simultan

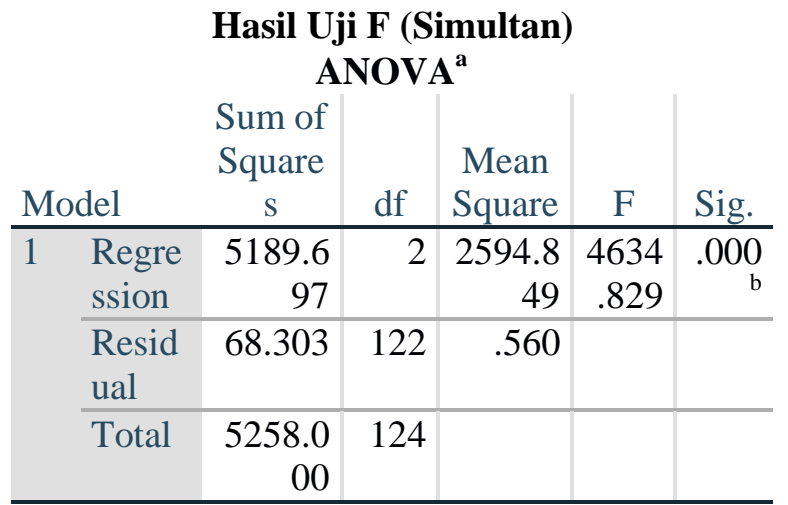

a. Dependent Variable: Kinerja

b. Predictors: (Constant), Disiplin,

Kepemimpinan

Hasil perhitungan statistik uji $\mathrm{F}$, diketahui nilai $\mathrm{F}_{\text {hitung }}=4634.82$ lebih tinggi dari nilai $\mathrm{F}_{\text {tabel }}$ yaitu 2,78 . Taraf signifikansi seluruh variabel bebas ]

secara simultan $(0,000)$ lebih kecil dari 0,05 , yang berarti hipotesis dalam penelitian ini menerima $\mathrm{Ha}$ dan menolak $\mathrm{H}_{0}$. Dengan demikian dapat disimpulkan bahwa Hipotesis 3 "kepemimpinan dan disiplin mempunyai pengaruh postif dan signifikan terhadap kinerja karyawan" diterima.

\section{Regresi Linier Berganda Hasil Uji Regresi Berganda Coefficients $^{\mathrm{a}}$}

\begin{tabular}{|c|}
\hline Unstanc \\
\hline $\begin{array}{c}\text { ed } \\
\text { Coefficients }\end{array}$ \\
\hline Std. \\
\hline
\end{tabular}

\begin{tabular}{ll|r|r|r|r} 
Model & B & Error & Beta & \multicolumn{1}{c}{ t } & Sig. \\
\hline $1 \begin{array}{l}\text { (Consta } \\
\text { nt) }\end{array}$ & 3.389 & .750 & & 4.51 & .000 \\
\hline $\begin{array}{l}\text { Kepem } \\
\text { impina } \\
\text { n }\end{array}$ & .048 & .016 & .048 & 2.98 & .003 \\
\hline $\begin{array}{l}\text { Disipli } \\
\text { n }\end{array}$ & 1.000 & .017 & .956 & 58.7 & .000 \\
\hline
\end{tabular}

a. Dependent Variable: Kinerja

Dari tabel di atas, diperoleh hasil perhitungan sebagai berikut: Berdasarkan hasil perhitungan uji regresi berganda yang terdapat pada tabel diatas, dapat diketahui persamaan regresi yang terbentuk adalah : $Y=3.389+0,048 X 1+1,000$ $X 2$

Variabel kepemimpinan dan disiplin mempunyai koefisien yang bertanda positif terhadap variabel 
kinerja karyawan. Koefisien variabel kepemimpinan memberikan nilai sebesar 0,048, yang berarti bahwa jika variabel kepemimpinan semakin baik dengan asumsi variabel lain tetap maka variabel kinerja karyawan akan mengalami peningkatan. Koefisien disiplin memberikan nilai sebesar 1.00 yang berarti bahwa jika variabel disiplin semakin baik dengan asumsi variabel lain tetap maka kinerja karyawan akan mengalami peningkatan.

\section{Uji Koefisien Determinasi}

\section{Hasil Uji Koefesien Determinasi Variabel \\ Kepemimpinan (X1) dan Disiplin (X2) terhadap Kinerja Karyawan (Y) Model Summary ${ }^{\mathrm{b}}$}

\begin{tabular}{ll|r|r|r}
$\begin{array}{l}\text { Mod } \\
\text { el }\end{array}$ & R & $\begin{array}{c}\text { R } \\
\text { Square }\end{array}$ & $\begin{array}{c}\text { Adjusted } \\
\text { R Square }\end{array}$ & $\begin{array}{c}\text { Std. Error } \\
\text { of the } \\
\text { Estimate }\end{array}$ \\
\hline 1 & $.993^{\mathrm{a}}$ & .987 & .987 & .748 \\
\hline
\end{tabular}

a. Predictors: (Constant), Disiplin, Kepemimpinan

b. Dependent Variable: Kinerja

Berdasarkan hasil output SPSS dalam tabel diatas, diketahui bahwa nilai $R$ Square $\left(R^{2}\right)$ adalah sebesar 0,987 dimana nilai tersebut masuk pada kategori sangat kuat. Sehingga, dapat disimpulkan bahwa variabel kepemimpinan dan disiplin secara simultan memiliki pengaruh positif terhadap kinerja dengan perolehan nilai sebasar $98,7 \%$, sedangkan sisanya yaitu sebesar $1,3 \%$ ditentukan oleh faktor-faktor lain yang tidak diteliti dalam penelitian ini.

Berdasarkan hasil pengujian secara statistik diatas, selanjutnya akan dilakukan pembahasan terkait pengaruh dari masing-masing variabel bebas yaitu variabel Kepemimpinan (X1), dan variabel Disiplin (X2) terhadap variabel terikat yaitu Kinerja Karyawan (Y) pada PT. Indosat, Tbk Jakarta Selatan.

Hasil pengujian hipotesis kepemimpinan menunjukkan nilai $t$ hitung sebesar 4,111 lebih tinggi dari nilai $t_{\text {tabel }}$ yaitu 1,657. Taraf signifikansi variabel kepemimpinan adalah $(0,000)$ lebih kecil dari 0,05 yang berarti bahwa hipotesis dalam penelitian ini menerima $\mathrm{Ha}_{1}$ dan menolak $\mathrm{H}_{01}$. Dengan demikian dapat disimpulkan bahwa hipotesis $\mathrm{H}_{1}$ "Kepemimpinan mempunyai pengaruh positif dan signifikan terhadap Kinerja Karyawan” diterima

Hasil pengujian hipotesis disiplin menunjukkan nilai $t_{\text {hitung }}$ sebesar 3,29 lebih tinggi dari nilai $t_{\text {tabel }}$ yaitu 1,657. Taraf signifikansi disiplin adalah $(0,000)$ lebih besar dari 0,05 yang berarti bahwa hipotesis dalam penelitian ini menerima $\mathrm{H}_{\mathrm{a} 2}$ dan menolak $\mathrm{H}_{01}$. Dengan demikian dapat disimpulkan bahwa hipotesis $\mathrm{H}_{2}$ "Disiplin mempunyai pengaruh positif terhadap kinerja karyawan" diterima

Hasil perhitungan statistik uji $\mathrm{F}$, diketahui nilai $\mathrm{F}_{\text {hitung }}=4634.82$ lebih tinggi dari nilai $\mathrm{F}_{\text {tabel }}$ yaitu 2,78. Taraf signifikansi seluruh variabel bebas secara simultan $(0,000)$ lebih kecil dari 0,05 , yang berarti hipotesis dalam penelitian ini menerima $\mathrm{Ha}$ dan menolak $\mathrm{H}_{0}$. Dengan demikian dapat disimpulkan bahwa Hipotesis 3 "kepemimpinan dan disiplin mempunyai pengaruh postif dan signifikan terhadap kinerja karyawan" diterima. Berdasarkan hasil perhitungan uji regresi berganda yang terdapat pada tabel diatas, dapat diketahui persamaan

regresi yang terbentuk adalah : $\boldsymbol{Y}=\boldsymbol{Y}=$ $3.389+0,048 X 1+1,000 X 2$ dan berdasarkan uji regresi linier berganda diketahui bahwa nilai $R$ Square $\left(R^{2}\right)$ adalah sebesar 0,987 dimana nilai tersebut masuk pada kategori sangat kuat. Sehingga, dapat disimpulkan bahwa variabel kepemimpinan dan kompensasi secara simultan memiliki pengaruh positif terhadap kinerja dengan perolehan nilai sebasar 98,7\%, sedangkan sisanya yaitu sebesar $1,3 \%$ ditentukan oleh faktor-faktor lain yang tidak diteliti dalam penelitian ini.

\section{E. PENUTUP}

\section{Kesimpulan}

a. Kepemimpinan mempunyai pengaruh positif dan signifikan terhadap Kinerja Karyawan, dimana hasil pengujian hipotesis secara parsial (uji t), diperoleh nilai $t_{\text {hitung }}$ sebesar 4,111 lebih tinggi dari nilai $t_{\text {tabel }}$ yaitu 1,657. Taraf signifikansi variabel kepemimpinan adalah $(0,000)$ lebih kecil dari 0,05 .

b. Disiplin tidak mempunyai pengaruh terhadap Kinerja Karyawan, dimana hasil pengujian hipotesis secara parsial (uji t), diperoleh nilai $t_{\text {hitung }}$ sebesar 3.29 lebih tinggi dari nilai $t_{\text {tabel }}$ yaitu 1,657. Taraf signifikansi disiplin adalah $(0,000)$ lebih kecil dari 0,05. 
c. Kepemimpinan dan Disiplin mempunyai pengaruh secara bersama-sama terhadap kinerja karyawan, dimana nilai $\mathrm{F}_{\text {hitung }}=$ 4634,82 lebih tinggi dari nilai $\mathrm{F}_{\text {tabel }}$ yaitu 2,78. Taraf signifikansi seluruh variabel bebas secara simultan $(0,000)$ lebih kecil dari 0,05 , yang berarti hipotesis dalam penelitian ini menerima Ha dan menolak $\mathrm{H}_{0}$. Dengan demikian dapat disimpulkan bahwa Hipotesis 3 "kepemimpinan dan disiplin mempunyai pengaruh postif dan signifikan terhadap kinerja karyawan" diterima. Berdasarkan hasil perhitungan uji regresi berganda yang terdapat pada

d. tabel diatas, dapat diketahui persamaan regresi yang terbentuk adalah : $\boldsymbol{Y}=\boldsymbol{Y}=$ $3.389+0,048 X 1+1,000 X 2$ dan berdasarkan uji regresi linier berganda diketahui bahwa nilai $R$ Square $\left(R^{2}\right)$ adalah sebesar 0,987 dimana nilai tersebut masuk pada kategori kuat. Sehingga, dapat disimpulkan bahwa variabel kepemimpinan dan kompensasi secara simultan memiliki pengaruh positif terhadap kinerja dengan perolehan nilai sebasar $98,7 \%$, sedangkan sisanya yaitu sebesar $1,3 \%$ ditentukan oleh faktor-faktor lain yang tidak diteliti dalam penelitian ini.

\section{Saran}

a. Diharapkan pimpinan sering menetapkan serangkaian tujuan dan mengajak karyawan untuk berpartisipasi mencapai tujuan perusahaan

b. Diharapkan perusahaan memperhatikan disiplin kerja para karyawan.

c. Diharapkan karyawan lebih memperhatikan hasil kerjanya sesuai dengan kompetensi yang ada pada perusahaan.

\section{DAFTAR PUSTAKA}

Bangun, wilson, 2012. Manajemen Sumber Daya Manusia, Erlangga, Jakarta.

Hasibuan, Malayu. 2012. "Manajemen Sunber Daya Manusia". Jakarta: PT Bumi Aksara
Kartono, 2014 : "Pemimpin dan Kepemimpinan". Jakarta : PT. Raja Grafindo PersadaKadarisman. (2012). Manajemen Kompensasi. Jakarta: Rajawali Pers.

Marwansyah.2014. Manajemen Sumber Daya Manusia, Bandung : ALFABETA

Nurfaiyah dan Anita Damajanti. 2012. "Pengaruh Motivasi, Kepemimpinan dan Budaya Organisasi Terhadap Kepuasan Kerja dan Kinerja Karyawan PT. Samwon Busana Indonesia".

Sedarmayanti, 2012, Manajemen Sumber Daya Manusia, Grasindo, Jakarta.

Sedarmayanti, 2013. Membangun dan Mengembangkan Kepemimpinan serta Meningkatkan Kinerja untuk Meraih Keberhasilan . bandung: Refika Aditama

Setiyadi, Eviana. 2013. "Pengaruh Gaya Kepemimpinan, Motivasi, dan Budaya Organisasi Terhadap Kinerja Karyawan Pengadilan Negeri Boyolali”. Skripsi S-1 (tidak diterbitkan). Fakultas Ekonomi dan Bisnis Universitas Muhammadiyah Surakarta.

Sugiyono, 2013, Metodelogi Penelitian Kuantitatif, Kualitatif Dan R\&D. (Bandung: ALFABETA)

Syahyuti. 2012. Defenisi, Variabel, Indikator dan Pengukuran dalam Ilmu Sosial, Bina Rena Periwara, Jakarta

Veithzal Rivai, 2014. Manajemen Sumber Daya Manusia Untuk Perusahaan : Dari Teori Ke Pratik. PT. Raja Grafindo Persada, Jakarta.

Wahjosumidjo, Wijayanti. 2013. Kepemimpinan Kepala Sekolah. Jakarta: Raja Grafindo Persada.

Wahjosumidjo. 2013. Kepemimpinan dan Motivasi. Jakarta: Ghalia Indonesia. 
Arih Syahroni, "Pengaruh Kompensasi Terhadap Kinerja Karyawan Pada PT.Indomarco Primatama Cabang Parung-Bogor". Skripsi S1 Fakultas Ekonomi Universitas Pamulang. Tangerang Selatan : 2017

Stiawan Bagus, "Pengaruh Gaya Kepemimpinan Terhadap Kinerja Karyawan Pada PT. Istana Kebon Jeruk Jakarta". Skripsi S1 Fakultas Ekonomi Univesitas Pamulang. Tangerang Selatan: 2016

Pasaribu, V. L. D., Krisnaldy, K., \& Warasto, H. N. (2020). Pengaruh Gaya Kepemimpinan, Disiplin Kerja Dan Kompensasi Terhadap Kinerja Pegawai (Studi kasus kelurahan Pisangan Ciputat). Jurnal Disrupsi Bisnis: Jurnal Ilmiah Prodi Manajemen, Fakultas Ekonomi, Universitas Pamulang, 3(1).

http://tesisdisertasi.blogspot.co.id/2010/10/dirnen si-indikator-motivasi.html? $\mathrm{m}=$

www.edefinisi.com. Definisi Uji Validitas, Reliabilitas, dan Uji Asumsi Klasik. (Diakses tanggal 17 Juli 2018).

http://www.bgl.esdm.go.id/

http://museum.geology.esdm.go.id/ 